Larisa PRODAN

Faculty of Letters, "Babeș-Bolyai” University

Cluj-Napoca, Romania

prodanlarisa29@gmail.com

\title{
CONTEMPORARY ART IN LIBERAL REGIMES. INTERVENTIONIST ART AND INSTITUTIONAL POWER
}

Recommended Citation: Prodan, Larisa. "Contemporary Art in Liberal Regimes. Interventionist Art and Institutional Power.” Metacritic Journal for Comparative Studies and Theory 5.1 (2019): https://doi.org/10.24193/mjcst.2019.7.10

Abstract: From the traditional interventionist or "regulatory" perspective, censorship has gained during the democratic era a "polymorphous nature," as Francesca Billiani designates it. Conceptual changes represent the base of the "new censorship," also known as "constitutive" or "structural," in terms conceptualized by Pierre Bourdieu. These new perspectives on censorship depart from the ideological restrictions specific to totalitarian regimes, while they are also defined by mechanisms of repressing intellectual freedom and speech. Thus, the present work aims to provide a case-study of "new censorship" applied to contemporary forms of art. The forms of censorship are presented as aiming to create beneficial ambience for consumerist development, as the art institutions, The Guggenheim Museum and The Metropolitan Museum of Art in New York, are involved in development negotiations with corporate companies. The censorship consisted in the direct interventions of the regulatory forces (museum guards and police officers) during the performative acts of Global Ultra Luxury Faction and The Illuminator Art Collective who manifested against the capitalist development of art. Despite the apparently traditional character of "regulatory censorship," the interventions previously mentioned could easily be classified in the "new censorship" typology, as these are meant to restrict freedom of opinion and artistic expression.

Keywords: censorship, interventionist art, participatory art, institutional power, freedom of speech 
Together with the "new scholarship", perspectives regarding the concept of censorship have significantly changed. However, to be more precise, what have developed are not only the scientific views of censorship, but also the censorship itself gaining new contours and understandings. The present work aims to outline the established relationship between art and what is already known as new censorship in the context of the globalisation era. The constitutive characteristics of art forms depart from traditional representations, realised through mimetic strategies, approaching those contemporary art manifestations seen as performative, participatory and even interventionist. In the present essay, I try to analyse and distinguish the different forms and mechanisms of regulation that contemporary censorship manifests. The discussion will be mostly directed towards interventionist movements meant to decline institutional power that became totally managed by consumerist purposes. A common point of the studied cases would be represented by restrictions and suppressions of free artistic discourse. The performative acts belong to the groups Global Ultra Luxury Faction and The Illuminator Art Collective who frequently manifest themselves against the capitalist development of art institutions - the museums - and even art itself. The study will follow some theoretical guidelines regarding "new censorship" so that the concept's characteristics could be easily recognised and applied to the discussion regarding the artistic movements. Moreover, of particular interest will be what interventionist, participatory art represents and the way it manifests in the democratic era. Last but not least, the interventionist manifestations of GULF and the Illuminator at The Guggenheim Museum, respectively The Metropolitan Museum of Art, New York, will be depicted and analyzed following the mechanisms through which these were censored. These cases of performative interventionist art have previously been tackled by Yates McKee in his book, Strike Art. In this essay, I will depart from McKee's perspective - the manner in which these movements are related to the Occupy Wall Street Movement and their significance for the status of art in a democratic era. The artistic events will be seen through the lens of censorship, the focus approaching the strategies of "new censorship," their impact on the performances and also the manner in which groups resisted limitations of free speech - if they did.

Consequently, following "new censorship" and its "polymorphous nature" (Francesca Billiani), I assume it would be appropriate to outline some of the most 
representative theoretical views regarding the emergence and becoming of censorship nowadays. In Pierre Bourdieu's view, censorship could be understood as a metaphor due to its development and departure from the restrictive mechanisms specific to ideological regimes. Democratic era meets censorship as an inner ("structural" or "constitutive") characteristic of form - one that not only "determines form," but represents the form itself, influencing even the "form of reception" (Bourdieu 139). In discussing the "misleading" character of what censorship has become, what Bourdieu tries to establish are some indicative limitations of the concept, in order to place it appropriately in the field of expression and language: "it is the structure of the field itself which governs expression by governing both access to expression and the form of expression, and not some legal proceeding which has been specially adapted to designate and repress the transgression of a kind of linguistic code" (Bourdieu 138).

Enlarging the understanding of censorship to such extents could lead to "equating censorship with any kind of social control" (Muller 1). Thus, in order not to fall into the extreme of interpretation, a differentiating path is necessary between censorship as such and other kinds of social control that could be intrinsic to the morality and well-proceeding of an ethical, democratic society. In Beate Muller's view, what remains of censorship when approaching acts of communication is "an authoritarian intervention by a third party into an act of communication between the sender of a message (the author) and its receiver (the reader), a message intended for the public but prevented from ever reaching it" (Muller 11). Therefore, despite its dichotomous and emblematic nature, censorship involves (in both eras: "regulatory" and "constitutive") a three-dimensional entity. The control is generally governed and determined by the entity in power. Access to communication (or information) between the sender and the receiver would always be managed by those in a position of control who exercise their power and regulation through censoring means.

Though settled in such a favourable - and sometimes profitable - position, the censor is in its turn censored by "environmental restraints" around him and present everywhere in the society nowadays. This is precisely what Michael Holquist calls "the paradox" of censorship: an irony given by censorship's morphology that, despite all implied "discursive hegemony," goes beyond prohibition and controls the "ecosystem" itself (Holquist 17). It is that specific "something" which humans and language cannot escape. This could be also due to the remaining or, better said, 
lasting of censorship through mechanisms of self-censorship even after the decline of censoring institutions in ideological regimes. Artistic and literary discourse, human behaviour and conduct are directly affected by means of restriction present all over in society. In the attempt to fit it and to be accepted, discourse and intellectual choices impose themselves strict delimitations. Therefore, their inner structure is affected and consequently modified according to censoring perspectives.

Following a similar argumentation, as well as an interconnected theoretical perspective on censorship, Robert C. Post agrees, in his studies, that censorship represents "the norm rather than the exception". In his view, the normative or regulatory character of censorship should not be offered such a significant relevance in defining the concept, because "censorship is" $(3,4)$. Post claims that censorship gained an omnipresent outlook along the years, as it became the main criterion in formatting "the practices that define us as social subjects" (4). Therefore, the "constitutive" and at the same time productive nature of censorship nowadays gives birth to possible misunderstandings and even difficulties in differentiating instances of power. This is precisely why "new censorship" does not represent only repressive mechanisms of the state in the name of security or decency, but mostly restrictions of language and expression in everything that is with regard to the public sphere:

The new censorship of silencing (...) tends to veer between the concrete mechanism of silencing and the abstraction of struggle. The result seems to flatten distinctions among kinds of power, implicitly equating suppression of speech caused by state legal action with that caused by the market, or by the dominance of a particular discourse, or by the institution of criticism itself (Post 4).

Within the same volume coordinated by Robert Post, Judith Butler distinguishes between explicit and implicit censorship. The concepts she proposes do not go beyond meaning, but stand as simple renamings or replacements of the two main types of censorship, in the attempt to outline and clarify features of each type. "Explicit" censorship refers to "state policy or regulation" - specific to "regulatory" censorship - while the "implicit" one stands for "operations of power that rule out in unspoken ways what will remain unspeakable" (249). What Butler tries to describe in here is the mere "structural" state of "new censorship" - regulation that is not explicitly manifested although it is present and in control of events. 
However, the author proposes an element of novelty in the mixture of terms and concepts relating to contemporary censorship. She relates it to foreclosure (249). In order to follow the origin of such concept, I would like to indicate that Butler's considerations regarding censorship have initially been introduced in her 1997 book Excitable Speech. Discussing censorship in terms of corporality and gender-related subjects, the author assumes a "transposition" of "foreclosure" from the psychoanalytic Lacanian field to the one specific to freedom of speech or freedom of artistic expression. Thus, "rethinking the way in which censorship acts," Judith Butler imposes "foreclosure" as a concept moving from within a "proper meaning into an improper one" (Butler 138). To put it more accurately, she sees this type of process not as singular but as multiple and continuous: there constantly takes place a "reinvocation" of a "primary scene in which the formation of the subject is tied to the circumscribed production of the domain of the speakable" (138). Thus, she very well specifies the strict distinction between speakable and unspeakable (what can and what cannot be said about a determined subject). When coming to censorship, the author tackles the distinction of the permissible from the impermissible, so that censorship is assumed as in between, a productive process that reveals the discursive:

On the assumption that no speech is permissible without some other speech becoming impermissible, censorship is what permits speech by enforcing the very distinction between permissible and impermissible speech. Understood as a foreclosure, censorship produces discursive regimes through the production of the unspeakable (139).

The variety of considerations and perspectives on what "new censorship" is and how its mechanisms function is "complemented" (as an extension of contexts and fields) by Francesca Billiani. In the introduction to Modes of Censorship and Translation the author sees censorship as a discourse - "the dominant one" - and widens its sphere of domination to economics and media. Cases or - as she calls them "scenarios" that could pass as «neutral» for the large public are precisely what produces for censorship the so-called polymorphous nature (3). Due to the extension into economics and media, censorship is thus offered an overall view and, furthermore, it is conferred spheres of action that go beyond literary and artistic discourse. In connection to the "paradox of censorship," Billiani attests its presence 
in the social media, being strongly related to the economics nowadays. The author refers to the "multifaceted nature" of censorship as having a considerable significance in maintaining the "normal" of things in clear-cut delimitations. In her view, the main aspect censorship restricts is "cross-cultural communication" by means of blocking or manipulating (3). The examples of performative artistic movements chosen for discussion in the present essay will reveal one of these "faces" of cross-cultural communication and interchangeable information. Entities in position of power would usually restrict access to information when coming to a multicultural artistic development and would prevent further undesirable artistic manifestations. In the process of "cross-cultural transfer" censorship therefore remains a narrow "filter" (4) that would allow "freedom" of expression only to some privileged entities in the detriment of others.

In what follows, the present study is dedicated to the phenomenon of contemporary art. This artistic field will be seen as one that departs from traditional strategies of creation. It would generally require not a singular, one-person audience but a large public that becomes incorporated in the artistic movement itself. Thus, in the first instance some theoretical guidelines will clear the general context and will emphasize the connection of such movements to the globalising era. Of particular interest will be the role of such artistic manifestations in the struggle with censorship of any kind. Then, specific contextualization will be offered, discussing the cases of Global Ultra Luxury Faction and The Illuminator Art Collective.

Within the multiple and varied studies upon contemporary art, there has been outlined the intrinsic connection between art and globalisation. The new globalising era produced a significant increase of audience when coming to contemporary art and its manifestations, favouring the raise of art institutions (public or private museums). The key-element when coming to processes of institutionalisation stands as an obvious fact the financing. Once institutionalized, access to exhibitions and manifestations has been significantly increased, artistic events generally reaching a world-wide audience (Griffin 7). According to Dumbadze and Hudson, "globalization is fundamental for understanding how institutional frameworks now shape contemporary art" (5). Art forms are in total dependence of the institutions they are included in and this has unfortunately provided positions of power and mechanisms of control and regulation. Could we deduce that the process of institutionalising art within the globalising era represented a form of censorship itself? Once the 
phenomenon had commenced, art needed to succumb to a multiple set of rules and regulations that brought a supplementary constraint to artistic expression. Further analysis will reveal aspects of art shaped through institutional power and control, favoured by such globalising consumerist mechanisms.

Nevertheless, the artistic perception is considered to be the representative change that contemporary art brought in the tradition of art. I refer here to the departure from the "one-to-one" relationship between the viewer and the work of art. Contemporary art nowadays requires a collective spectator that could possibly be involved in the artistic form itself. Claire Bishop names the phenomenon participatory art: "I will be referring to this tendency as 'participatory art', since this connotes the involvement of many people (as opposed to the one-to-one relationship of 'interactivity') and avoids the ambiguities of 'social engagement', which might refer to a wide range of work" (1). The focus in the artistic perspectives departs from those traditional mimetic representations of reality and approaches at the same time the human material: "people constitute the central artistic medium and material" (Bishop 2). Moreover, together with the spectator that becomes "a participant" in the work of art, the status of the artist is also changed. Primarily conceived as an "individual producer," the artist is considered "a collaborator and producer of situations" (2). Consequently, there could also be outlined the becoming of the artistic product itself: not a concrete material object, but more "an on-going or longterm project with an unclear beginning and end" (2). The work of art is automatically extended in the temporal field, gaining socially engaged features and purposes. In Bishop's view, when considering the "return to the social" of art, what matters is not the visual analysis anymore but the "documentary material" that gives access to artistic practices for a better and larger understanding of the public (3-5).

A noteworthy feature is also the transition from the visible to the "invisible". Participatory art does not require a definite image of the artistic work. What is truly valuable stays as "a group dynamic, a social situation, a change of energy, a raised consciousness" (6). Mainly perceived as "socially collaborative practices," participatory movements stand for a reunification of the fragmented and disseminated society. The causes for such dissemination are capitalist market strategies and therefore collective artistic manifestations are meant to be "gestures of resistance" (11-13). It is the resistance that could be conceived not as only political, 
but also as one that fights against social inequalities brought by consumerist development.

On the contrary, David Graeber places such movements under the sign of "new Anarchism". The anthropologist claims that "Anarchism is the heart of the movement, its soul" (Graeber 62). In his opinion, interventionist manifestations should be regarded as political rather than artistic. Such a vision cannot offer a complete certitude, but I consider it is a plausible perspective applicable and verifiable for many of the performative artistic movements. Furthermore, if performative manifestations are generally considered as bringing a critique towards globalisation, Graeber sees such considerations simply as a "coinage of the US media" (62). Whether the critique is directed towards the globalising mechanisms within the society or not when coming to such movements, I believe it depends again on proper contextualisation. It would be a misleading statement to claim that all the reactions to the contemporary artistic events are simple inventions or manipulative creations of the media. These come, many times, as proof of morality and ethical behaviour. In David Graeber's view, however, the actual target of such movements should be neoliberalism and not the globalising consumerist strategies of the society nowadays. This is mainly due to the fact that neoliberal politics are considered the only ones that indeed restrict human freedom and development.

Now however, despite the targeted instance of the receiver, what strikes in fact is the non-violent character of such movements. Graeber claims that the reason for the entities of power' violent interventions represent nothing less than a lack of knowledge. Such knowledge stays as double: towards the understanding of the actual purpose of the movement and also towards the manner in which manifestations could be peacefully managed: "governments simply do not know how to deal with an overtly revolutionary movement that refuses to fall into familiar patterns of armed resistance" (66). The thesis could also stand for the events at The Guggenheim Museum, New York, in the spring of 2014. Museum guards violently intervened during the manifestations in order to bring them to an end. A closer view upon the already mentioned events will be offered in the following paragraphs.

Thus, during the "Italian Futurism, 1909-1944: Reconstructing the Universe" show at Guggenheim Museum, New York, a large group of people invaded the rotunda of the museum and yet seemed, at the very beginning, average visitors. Suddenly, banners presenting "Wage Theft" and "1\% Museum" were shown off, 
together with a fall of leaflets and a "call-and-response chant" between the members of the group. Among their replies were: "Who is building the Guggenheim Abu Dhabi?"/ "Migrant workers in labour camps! Is this the future of art?" (Cotter). Museum representatives together with the guards violently cut the group' banners and abusively directed the crowd towards the exit. In order for the status of the museum to be preserved, doors were shut. At this point, the inevitable question intervenes: should it be perceived only as restrictive behaviour by the authorities so that the order of the museum could be maintained? Or should we see such intervention as a mechanism of censorship applied to a form of contemporary art? In discussing differences between traditional "regulatory" censorship and the "new" "constitutive" one, the museum's guards initiative could obviously be perceived through the lens of regulatory censorship. Nevertheless, if the analysis goes further, their action was meant to keep a certain order of the institution, - and here I would like to emphasize "institutional" as the inner characteristic of art in the globalisation era, in the terms of Francesca Billiani - by completely neglecting the artistic character of such manifestation. The guards' reaction, in my view, was part of a "structural" and organising field of the artistic discourse. Those in a position of power have the duty of controlling the very slight difference between what can and cannot be said (the "sayable" and the "unsayable") while they are - in their turn controlled and censored. Even if the movement was strongly related to the museum's plans of global development, it had to be kept apart from the space of the art institution, as if it had not had a direct reference to the museum or any feature of a work of art.

To extend explanations, the group is widely known as the Global Ultra Luxury Faction - or GULF, if abbreviated. It is affiliated with other two groups - Gulf Labor and Occupy Museums (Cotter), all together having a struggle for the rights of workers in the labour camps from Abu Dhabi. There, in the Saddiyat Island, a multimillion extension of The Guggenheim Museum was being built at the time, together with others belonging to world-wide known institutions of art such as Louvre Museum or British Museum. In that specific evening at Guggenheim, GULF protested for the extremely low-paid workers and the poor conditions of living they were offered. Workers were brought from South Asia to the Saddiyat Island - "Island of Happiness" (Cotter) - on the basis of a proper place of work. However, those in 
charge of managing the construction of the multimillion wing of Guggenheim Museum followed only their own financially profitable purposes.

Of particular interest, an this point, is the response of Guggenheim's director to the GULF manifestation. In his public statement, he definitely denied the existence of the construction. The director claimed that "complaints were misplaced" as the construction "had not yet begun at the time of the demonstration" (Cotter). In response to such declarations, GULF particularly argued that the proceedings had indeed started for several years and the conditions of living offered to workers were on the edge of slavery:

Right now, the Guggenheim Abu Dhabi's infrastructure is being constructed. That infrastructure includes roads, sewage, water, electric, net pipes, etc., leading to the museum. But other components of the work are also under way. We can only assume that money has been transferred to the Guggenheim here in New York in order to hire the curators and administrators of Guggenheim Abu Dhabi (Joseph).

Due to such statements, the case presents a serious restriction from free access to information. The real state of things is hidden from the public eye and voices that try to actually bring a change are silenced. Thus, censorship intervenes in the artistic discourse, becoming the discourse itself. Considering themselves as the only ones who own legitimacy, censors try to cancel the statement of validity in the discourse of the other. The situation depicted is meant to be seen through the lens of power. Those in such positions are capable of formatting and manipulating public opinion and discourse.

In addition, another of the GULF's requirements was a direct dialogue with the museum's administration. Nevertheless, it was completely avoided. The refusal of dialogue and negotiation represents one more time an infringement on democratic practices. In order to preserve PR politics and strategies, museum administrations falls - I could claim - in the "consumerist trap" by neglecting human rights (and also access to free speech) for purely and rather significant economic benefits and concerns: "the Guggenheim was doing at the very least a convincing impersonation of a globalizing corporation with new headquarters, built by and for the rich at the expense of the poor, to supply a luxury leisure and tourist spot in the Middle East 
with global art exhibitions" (Cotter). This fits extremely well with Francesca Billiani's assumption that contemporary forms of censorship produce restriction to a "crosscultural communication," using mechanisms of "blocking" and "manipulation".

In connection to David Graeber's claims regarding the target of such movements - neoliberalism -, Chloe Wyma sustains that the events are a proof of "Guggenheim's decades-long neoliberal turn". In her view, the museum has transferred its focus from an institution of modern art to a "neoliberal art franchise" coordinated by corporate funding. These financial investments brought a significant impact upon artistic discourse. Entities in power in such "for-profit enterprises" influence the on-going process of art from an almost dictatorial perspective. It does therefore represent a "constitutive" censorship in the structure of artistic discourse and public opinion themselves.

Furthermore, in what follows, I expose another case of artistic discourse fragmented and even prohibited by institutional power due to consumerist purposes of development. To be more precise, three members of The Illuminator Art Collective were arrested one evening during an interventionist manifestation, in the same year. They were accused of "Unlawful Posting of Advertisements" (Vartanian) as they projected slogans onto the façade of The Metropolitan Museum of Art. Their action represented a protest against the collaboration between the museum and the wellknown billionaire David H. Koch. The manifestation happened during a gala celebrating the inauguration of David H. Koch Plaza (Friedman). After the projection of the following message: "KOCH = CLIMATE CHAOS," the detention of three members of the Illuminator Collective supervened. Their projecting equipment was also confiscated as "evidence".

Police intervention could be again seen as a restraint of free artistic speech, action that goes beyond regulatory mechanisms of censorship. It is meant to change and at the same time to cancel undesired speech that could publicly reveal hidden truths. Moreover, a prevention of such further public interventionist manifestations is also sought: "obviously used as a ploy to remove us from the scene before our message was met by too many eyes" (Vartanian). In its attempt to place the movement under the sign of illegality, in my view, police forces intervened against a possible exceeding into the field of the "impermissible" (a term that Judith Butler proposes, as previously discussed). In order for the movement to not reveal more, to 
not further disturb more targeted personalities in the event, they preferred to directly silence them.

Of significant importance in the present case is the confiscation of the projector - apparatus considered as a label for the group and for their art. After the three arrested members of the Illuminator (Kyle Depew, Grayson Earle, and Yates McKee) were released, their projector was kept into custody for "an additional two months and 10 days" (Vartanian). It was an obvious attempt at restricting and cancelling future manifestations - which worked, since the Illuminator and their movements were directly affected by such custody. According to Kyle Depew's claims, they generally use such device "to smash the myths of the information industry and shine a light on the urgent issues of our time" (Friedman). Thus, they fight against informative manipulation and, through their art, technical lights are brought at the level of an artistic metaphor. "Issues of our time," issues strongly connected to our society nowadays are "lighted on" in order to be clearer perceived by the large public. Overall, the Illuminator Collective's manifestation represented in a way or another a politically engaged art restricted by contemporary mechanisms of censorship.

In their defence, the lawyer stated it was indeed an infringement on The First Amendment: "The First Amendment was established to ensure that the government could not use its power to restrain speech on the basis of its message, or the identity of the speaker" (Vartanian). Instances of power restricted group rights to free speech in a very explicit manner due to the powerful substrate of their engaged artistic discourse that clearly affected them. In my opinion, the case could stand as representative for Judith Butler's "foreclosure". Censorship acts as clearly distinguishing between "permissible" and "impermissible" and in this specific foreclosure the "discursive regime" is produced. Explicitly delimitating the "production of the unspeakable," censorship constitutes itself as an autonomous discourse that allows or not future areas of artistic expression and public speech.

Additionally, the charge seemed to be totally groundless and even depicting false statements. It described the events by showing the artists as having financial benefits due to the public manifestation. Such claiming is nothing more than an attempt to cancel any artistic and benevolent characteristic the movement could have: 
If you really dissect that charge, though, you see how nefarious the whole thing really is. The charge stipulates, in a nutshell, that we permanently affixed something to the surface and stood to benefit financially from that action. Obviously neither of these applies to us whatsoever, as we are using video projection and certainly weren't standing to gain any commercial success from our endeavour (Vartanian).

Moreover, here intervenes again the attempt to manipulate information and consequently public opinion. The "cross-cultural transfer" that Francesca Billiani mentions is not only directly "blocked" by police force's intervention, but it is also manipulated. Information should not cross borders - not even those of knowledge. Thus, false statements are brought. It definitely represents a manipulation by cancelling the interlocutor's argument through means of invalidity and immorality.

To conclude, the contemporary mechanisms of censorship depart from those specific to ideological regimes. In the context of the globalising era, changes have occurred in censorship's inner metamorphosis. What is known in the theoretical field as "new censorship" is expressed through multiple restrictions and regulations upon public and artistic discourse. Thus, art that gains in the aforementioned era social features is strongly restricted by strategies of formatting discourse and this is due to consumerist purposes of development. Globalising ideals influence the sphere of art, its institutionalisation procuring forms and instances of power. As the financial field is of particular importance, contemporary art manifestations are rigorously controlled by those in power. Even if art has become nowadays a socially engaged one, its actual purposes are neglected and the cases of Global Ultra Luxury Faction and the Illuminator Collective represent proper examples of silenced art movements, not allowed to pass the barrier of the unsayable. In order to continue their plans of development without any possible interruptions from the public, the management of Guggenheim Museum tried to manipulate information so that they could easily manage public opinion. The Illuminator case is an explicit example of restriction to free artistic discourse. The artistic character of both movements is neglected by the entities in power. Free discourse is censored one way or the another by all the multiple censoring mechanism in place. All in all, contemporary censorship has become infiltrated in the mere constitutive field of discourse, imposing itself as natural, as perfectly fitting the normativity settled in the social conduct. 


\section{References:}

Billiani, Francesca, editor. Modes of Censorship and Translation: National Contexts and Diverse Media. Routledge, 2014.

Bishop, Claire. Artificial Hells: Participatory Art and the Politics of Spectatorship. Verso, 2012.

Bourdieu, Pierre. "Censorship and the imposition of form." Language and Symbolic Power, edited by John B. Thompson, translated Gino Raymond and Matthew Adamson. Polity Press, 1992.

Butler, Judith. "Ruled Out: Vocabularies of the Censor." Censorship and Silencing. Practices of Cultural Regulation, edited by Robert C. Post. The Getty Research Institute, 1998.

Butler, Judith. Excitable Speech. A Politics of the Performative. Routledge, 1997.

Cotter, Holland. "Door to Art of the World, Barely Ajar.” New York Times, March 19, 2014: https://www.nytimes.com/2014/03/20/arts/artsspecial/door-to-art-ofthe-world-barely-ajar.html?smid=pl-share. Accessed March 26, 2019.

Friedman, Julia. "Three Arrested, Charged in Koch Plaza Protest at Metropolitan Museum.” hyperallergic, $\quad$ September 12, 2014: https://hyperallergic.com/148627/three-arrested-charged-in-koch-plazaprotest-at-metropolitan-museum/. Accessed on the $27^{\text {th }}$ of March 2019.

Graeber, David. "The New Anarchists." New Left Review 13, January, February, 2002.

Griffin, Tim. "Worlds Apart: Contemporary Art, Globalization, and the Rise of Biennials." Contemporary Art: 1989 to the Present, edited by Alexander Dumbadze and Suzanne Hudson, Wiley - Blackwell, 2013.

Holquist, Michael. Corrupt Originals: The Paradox of Censorship. In PMLA, 109 (1), 1994.

Joseph. "Week 20. G.U.L.F. (Global Ultra Luxury Faction). Is This the Future of Art?.” gulflabor, February 27, 2014: https://gulflabor.org/2014/week-20-g-u-lf-global-ultra-luxury-faction-is-this-the-future-of-art/. Accessed on the $26^{\text {th }}$ of March 262019.

McKee, Yates. Strike Art. Contemporary Art and the Post-Occupy Condition. Verso, 2016. 
Muller, Beate. "Censorship and Cultural Regulation: Mapping the Territory." Censorship and Cultural Regulation in Modern Age. Critical Studies vol. 22, Rodopi, 2004.

Post, Robert C., editor. Censorship and Silencing. Practices of Cultural Regulation. The Getty Research Institute, 1998.

Vartanian, Hrag. "Members of the Illuminator Sue NYPD for False Arrest, First Amendment Retaliation,” hyperallergic, May 21, 2015: https://hyperallergic.com/209080/members-of-the-illuminator-sue-nypd-forfalse-arrest-first-amendment-retaliation/. Accessed on the 28 $8^{\text {th }}$ of March 2019.

Wyma, Chloe. "1\% Museum: The Guggenheim Goes Global.” dissentmagazine, Summer 2014: https://www.dissentmagazine.org/article/1-museum-theguggenheim-goes-globalon. Accessed on the $26^{\text {th }}$ of March 2019. 